BOOK REVIEW Collection (CODIMAR)

RESEÑA DE LIBRO

\title{
Guía Taxonómica Ilustrada de la Colección de Dinoflagelados Marinos (CODIMAR)
}

por Lourdes Morquecho-Escamilla, Amada Reyes-Salinas y Yuri B. Okolodkov

Dr. Alejandro M. Maeda-Martínez ${ }^{1}$

Cemo una publicación científica del
Centro de Investigaciones Biológicas del

Noroeste, S.C. (CIBNOR) salió a la luz en el 2016

la Primera Edición del libro “Guía Taxonómica

Ilustrada de la Colección de Dinoflagelados

Marinos (CODIMAR)" cuyos autores son

los especialistas Dra. Lourdes Morquecho-

Escamilla y M. en C. Amada Reyes-Salinas del

Laboratorio de Taxonomía y Ecofisiología de

Microalgas Marinas del Programa de Planeación

Ambiental y Conservación del CIBNOR, y Dr.

Yuri B. Okolodkov del Laboratorio de Botánica

Marina y Planctología del Instituto De Ciencias

Marinas y Pesquerías de la Universidad

Veracruzana.

El libro, aparte de ser una Guía bilingüe magníficamente ilustrada con 211 fotografías y redactada de manera ejemplar, es una
$\Lambda$ $s$ a scientific publication of Centro de LInvestigaciones Biológicas del Noroeste, S.C. (CIBNOR), the First Edition of the book "Illustrated Taxonomic Guide of the Marine Dinoflagellate Collection (CODIMAR)" was published in 2016, whose authors are the specialists Lourdes Morquecho-Escamilla, D.Sc. and Amada Reyes-Salinas, M.Sc. adscribed to CIBNOR Taxonomy and Ecophysiology of Marine Microalgae Laboratory of the Environmental Planning and Conservation Program and Dr. Yuri B. Okolodkov to Planktology and Marine Botany Laboratory of Instituto de Ciencias Marinas y Pesquerías of Universidad Veracruzana.

The book is not only a bilingual guide illustrated splendidly with 211 photographs and written in an unprecedented manner but 
obra introductoria muy completa al tema y problemática de las Floraciones Algales Nocivas (FAN), que por su actual importancia es por lo tanto una obra pertinente y necesaria en su campo de estudio.

El libro es ejemplar por su contenido y organización. Contiene un Prólogo escrito de manera experta por la Dra. Beatriz Reguera del Instituto Español de Oceanografía del Centro Oceanográfico de Vigo, en el que resalta la importancia de la obra a nivel local, nacional y global. El libro es una fuente documentada sobre los impactos ambientales y socio-económicos de las FAN y sobre el conocimiento actual de la Biodiversidad de los Dinoflagelados Marinos. Presenta amplia información sobre alcaloides neurotóxicos producidos por estos organismos como las Saxitoxinas (STX) que pueden afectar severamente a la salud humana, a organismos marinos como moluscos y peces, y a granjas acuícolas.

Sobre la cantidad y extensión del trabajo, la obra es el resultado de 16 años de estudios sobre Dinoflagelados Marinos desde inicios el año 2000 formando la CODIMAR, desarrollando actividades curatoriales del más alto nivel como son el Aislamiento a partir de estadios vegetativos y estadios quísticos, el Cultivo logrando su conservación ex situ, y la Identificación con apoyo de Microscopía de luz also a very complete introductory work to the topic and problems of harmful algal blooms (HAB). Because of their current importance, it is therefore a pertinent and necessary work in its field of study.

The book is a model because of its content and organization. It contains a prolog written with the expertise of Dr. Beatriz Reguera of Instituto Español de Oceanografía, Centro Oceanográfico at Vigo, where she highlights the importance of this work at national and global level. It is a documented source on environmental and socioeconomical impacts of $\mathrm{HAB}$ and on current knowledge of marine dinoflagellate biodiversity. The book provides broad information on neurotoxic alkaloids produced by these organisms, such as saxitoxins (STX) that could affect human health, marine organisms, such as mollusks and fish, and aquaculture farms severely.

With respect to the amount and extension of this work, it is the result of 16 years of study of marine dinoflagellates since the beginning of the year 2000 forming CODIMAR and developing top level curatorial activities, such as: Isolation, starting from vegetative and cystic stages; Culture, achieving its conservation ex situ; and Identification, with the support of light microscopy and scanning electron microscopy. Sixteen years of constant and high quality 
y Microscopía electrónica de barrido.

Los 16 años de trabajo constante y de alta work are demonstrated with the publication of 26 scientific articles that involve the use of

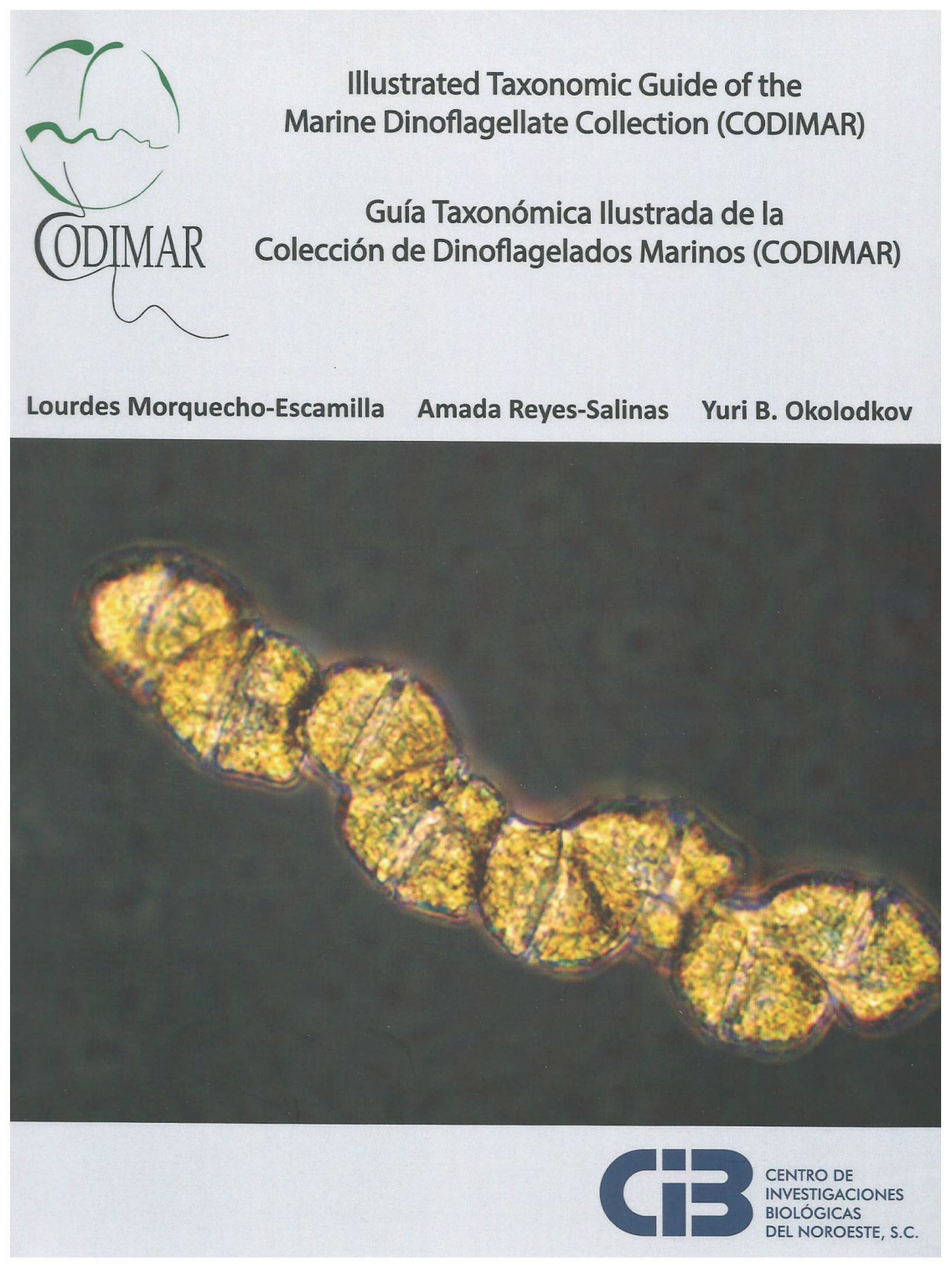

calidad se demuestra con la publicación de 26 artículos científicos que involucran el uso de organismos de la CODIMAR. La consolidación de esta colección científica se alcanzó gracias al desarrollo de un proyecto apoyado por la CONABIO (2011-2014) logrando ser
CODIMAR organisms. The consolidation of this scientific collection was achieved thanks to the development of a project with the support of the National Commission for Knowledge and Use of Biodiversity (CONABIO 20112014), which made it a registered collection in 
una Colección Registrada en el Padrón de Colecciones Científicas y Museográficas Públicas o Privadas de Especímenes Silvestres y en el Padrón de Prestadores de Servicios vinculados con la comercialización de ejemplares de vida silvestre de la SEMARNAT.

La CODIMAR es una colección computarizada y registrada en el Sistema Nacional de Información sobre Biodiversidad (SNIB) de la CONABIO. Cuenta con 26 especies, incluyendo las más nocivas de México, y ahora de alcance internacional con organismos representantes de Cuba.

La Guía Taxonómica Ilustrada de la Colección de Dinoflagelados Marinos (CODIMAR) se compone de dos grandes secciones; la primera en la que se desarrollan la Introducción y los temas sobre Cobertura geográfica y localidades, Prácticas curatoriales, Uso de las cepas de la CODIMAR y las Referencias. En el tema de la Cobertura geográfica se proporcionan descripciones precisas de las localidades, su geografía, características ecológicas, carácterísticas oceanográficas e impactos humanos. Se proporciona información detallada sobre la distribución de las especies, como Gymnodinium catenatum, Pyrodinium bahamense, Cochlodinium polykrikoides, Gambierdisus sp. y Prorocentrum lima.

En la segunda sección del libro se presentan 26 fichas taxonómicas con láminas fotográficas the registry Padrón de Colecciones Científicas y Museográficas Públicas o Privadas de Especímenes Silvestres and in Padrón de Prestadores de Servicios, registry linked with commercialization of wildlife specimens, of the Ministry of the Environment and Natural Resouces (SEMARNAT, for its acronym in Spanish) in Mexico. CODIMAR is a computerized and registered collection in the National Biodiversity Information System (SNIB, for its acronym in Spanish) of CONABIO. It has 26 species, including the most harmful of Mexico, and now of international reach with representative organisms of Cuba.

The Illustrated Taxonomic Guide of the Marine Dinoflagellate Collection (CODIMAR) comprises two large sections. The first one develops the Introduction and topics on Geographical coverage and localites, Curatorial Practices, Use of CODIMAR strains, and References. The topic Geographical coverage provides precise descriptions of the localities, geography and ecologic and oceanographic characteristics, and human impacts. Detail information is provided on species distribution, such as Gymnodinium catenatum, Pyrodinium bahamense, Cochlodinium polykrikoides, Gambierdisus sp. and Prorocentrum lima.

The second section of the book shows 26 taxonomic record cards with original 
originales, las características taxonómicas y morfológicas de dinoflagelados aislados principalmente del sur del Golfo de California y de aguas costeras de Cuba, finalizando con un siempre bienvenido Glosario. En las fichas se proporciona excelente información sobre las carácterísticas autoecológicas, su identificación taxonómica a través de microscopía de luz de campo claro, contraste defases, epifluorescencia y de microscopía electrónica de barrido, y sobre la identidad bioquímica y genética (ADNr), cinética de crecimiento y biología reproductiva tanto de las especies como de las cepas. Asimismo se proporcionan Notas taxonómicas sobre morfología, tamaño, forma de vida, notas biológicas, notas ecológicas, habitat y distribución y efectos dañinos.

Fundamentados en el documento vigente del Código Internacional de Nomenclatura de Algas, Hongos y Plantas, los autores señalan que la CODIMAR resguarda ejemplares de los órdenes Gonyaulacales, Gymnodiniales, Piridiniales y Prorocentrales distribuidos en 26 especies y 152 cepas vivas.

Como conclusiones de esta reseña se puede señalar que esta guía taxonómica bilingüe es un Libro introductorio muy completo al tema de las FAN, es una fuente autorizada sobre la Autoecología de los Dinoflagelados Marinos cultivados en la CODIMAR. Es una obra pertinente en su campo de estudio, ejemplar photographs, taxonomic and morphologic characteristics of dinoflagellates isolated mainly of the southern Gulf of California and coastal waters of Cuba, ending with an always welcomed Glossary. The record cards provide excellent information on the autoecologic characteristics, taxonomic identification through bright-field light microscopy, phase contrast, epifluoresence and scanning electron microscope, biochemical and genetic identidenty (ADNr), growth kinetics and reproductive biology of both species and strains. Likewise, taxonomic notes are provided on morphology, size, life form, biologic and ecologic notes, habitat and distribution, and harmful effects. Based on the current document of the International Code of Nomenclature (ICN) for algae, fungi and plants the authors mention that CODIMAR safeguards specimens of the orders Gonyaulax, Gymnodiniales, Piridiniales and Prorocentrales distributed in 26 especies and 152 live strains.

To conclude this review, it should be highlighted that this bilingual taxonomic guide is a very complete introductory book to the HAB topic and an authorized source on autoecology of the marine dinoflagellates cultured at CODIMAR. It is a pertinent work in its field for its content, organization, excellent 
por su redacción, por su contenido y su photography, updated reference sources, organización, por sus excelentes fotografías, and a model for its editorial impression. fuente de referencias actualizadas y ejemplar Congratulations for the publication of this por su impresión editorial. Muchas felicidades work to the authors Dr. Lourdes Morquechopor la publicación de esta obra a sus autores Escamilla, M.Sc. Amada Reyes-Salinas and Dr. Dra. Lourdes Morquecho-Escamilla, M. en C. Yuri B. Okolodkov. Amada Reyes-Salinas y Dr. Yuri B. Okolodkov.

Diseño Editorial: Lic. Gerardo Hernández Edición en Ingles: D. Dorantes 